\title{
福井県水島の海浜変形の実態と地形変化予測

\author{
Beach Changes of Mizushima Island in Fukui Prefecture and their Prediction
}

\author{
宇多高明 ${ }^{1} \cdot$ 野志保仁 $^{2} \cdot$ 星上幸良 $^{3} \cdot$ 过岡雄樹 $^{4} \cdot$ 西村隆吉 $^{4}$ \\ Takaaki UDA, Yasuhito NOSHI, Yukiyoshi HOSHIGAMI \\ Yu-uki TSUJIOKA and Takayoshi NISHIMURA
}

\begin{abstract}
Mizushima island located in Tsuruga Bay is a famous recreational beach in Fukui Prefecture. This beach has been eroded in recent years. The topographic changes and tide level changes at Tsuruga Port were measured. On the basis of these field data, the contour-line-change model proposed by Noshi et al. was applied to the prediction of beach changes. It was concluded that beach changes closely relate to the wave action along with the increase in tide level during passage of low pressure in summer.
\end{abstract}

\section{1.はじめに}

わが国では各地で海岸侵食が進んできている，その直 接的原因は波浪の作用にあるが，多くの場合人為的改変 の影響がその引き金になっている $(\mathrm{Uda}, 2010)$.とくに 長い海岸線を有する砂浜海岸での侵食では, 人為改変の 影響を無視できない。著しい侵食をもたらす海浜変形の 主な要因として，宇多（2004；2010）は，1河川流出土 砂量の減少に伴い沿岸漂砂との均衡が失われて河口周辺 海岸で侵食が進む場合，(2)卓越沿岸漂砂が防波堤など海 岸線と直角方向に延ばされた構造物により阻止され，下 手側海岸で侵食が進む場合，(3)防波堤が沖合に伸ばされ て周辺の波浪場が変化し, 波の遮蔽域の外側から内側へ と沿岸漂砂が誘起され，これによって周辺域が侵食され る場合などに分類した。これらの要因によって海浜変形 が起きた例は数多いが，島の周辺でも同種の海浜変形が 生じることもある. 福井県敦賀半島先端部に位置する水 島がその例である。この島は半島先端部にある小島であ り，上記侵食原因の分類に乗りにくい例である．水島は 福井県有数の自然豊かな島の海水浴場として利用されて きており，1980年代以降その変形が大きな問題となった. 宇多ら（2011）は，過去からの水島の変遷を空中写真の 比較，深浅測量などにより調べるとともに，波浪・海浜 流の計算を行いその変形の原因について考察し，海浜変 形が突堤建設に起因することを突き止めた。本研究は前 報に続くものであり，水島での海浜地形変化を実測する とともに，地形変化と密接に関連する低気圧通過時の潮

\begin{tabular}{|c|c|c|}
\hline 1 正会員 & 工博 & $\begin{array}{l}(\text { 財) 土木研究センター常務理事なぎさ } \\
\text { 総合研究室長兼日本大学客員教授理工学 } \\
\text { 部海洋建築工学科 }\end{array}$ \\
\hline 2 正 & 博 (工) & (有)アイコムネット＼cjkstart環境コンサルテイング部 \\
\hline 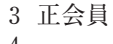 & 博 (工) & 国際航業株式会社河川環境部 \\
\hline 4 & & 福井県土木部砂防海岸課 \\
\hline
\end{tabular}

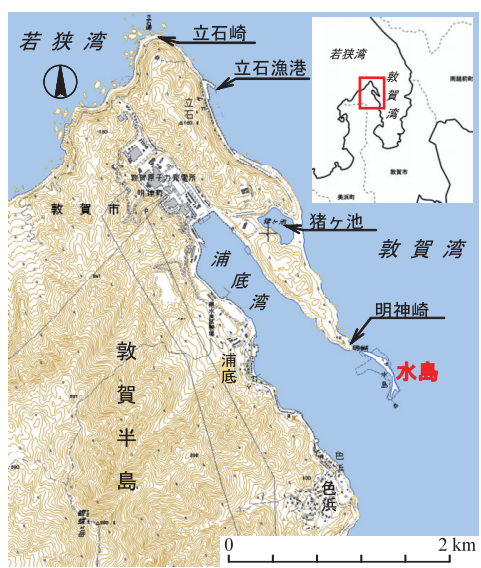

図-1＼cjkstart敦賀湾内における水島の位置

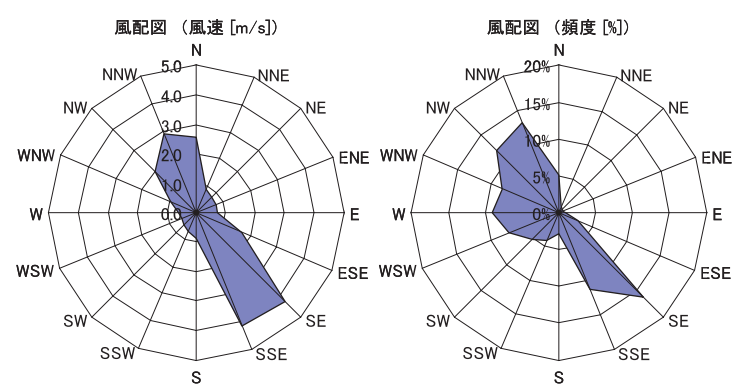

図-2 敦賀発電所における通年の方向別出現頻度と方向別平均 風速（2006～2008年）

位の変動を調べ，これらをもとに野志ら（2008）の等深 線変化モデルによる計算を行い，実測の海浜変形が低気 圧襲来時の潮位上昇と深く関倸することを明らかにする.

\section{2. 水島の地形と風特性}

水島は福井県の敦賀湾湾口部に位置し，若狭湾国定公 園に含まれる面積約 $1.5 \times 10^{4} \mathrm{~m}^{2}$ の小島である（図-1). 敦 
賀湾は東西の幅が $7.1 \mathrm{~km}$, 奥行きが $11.8 \mathrm{~km}$ の細長い湾で あり，湾口は北西方向に開いている，湾口には立石崎が あり, 海岸線は立石崎からほぼ南東方向に伸び，その先 端の立石崎から約 $3.6 \mathrm{~km}$ に水島が位置する．立石崎から 南東方向に伸びた半島はその南側には浦底地溝（浦底湾） を抱える。また半島のほぼ中央には㗂堤で囲まれた猪ケ 池を擁する，半島の南東端は明神崎であり，水島との間 には狭い開口部がある。地形的に見て冬季の風浪は湾口 から南東方向へと侵入するため, 立石崎からほぼ南東方 向に伸びる海岸線に沿って南東方向への沿岸漂砂が発達 する．水島は立石崎から伸びる岩石海岸から沿岸漂砂に より運ばれた砂砂が堆積して形成されたと推定できる. 地質的には花崗岩地域に位置する（福井県，2010）ため 海岸線には固い岩が堆積している.

敦賀湾は南北に細長い形状であり，水島への来襲波は 湾口（NW）からの冬季風浪と，SEまたはSSE方向の風 により発達する湾内風波が卓越する．水島の北西約 3.4 $\mathrm{km}$ に位置する日本原子力発電（株）敦賀発電所構内で観 測された 2006〜2008年の気象観測データによる，通年 の方向別出現頻度と方向別平均風速を図-2 に示す. 風向 の出現頻度はSEが16\%で最も高く, NNWが13\%でこれ に次ぐ. 方向別平均風速はSEおよびSSEがほぼ $4 \mathrm{~m} / \mathrm{s}$ と 他の方向より強風である。また季節別にはSEまたはSSE 方向の風は5 月から 8 月までほぼ似たパターンで出現す ることから，湾内風波は夏季の風により強く支配される ことが分かる.

\section{3. 水島の浦底湾側の海浜変形}

2009年10月測量の水島周辺の深浅図を図-3に示す．図 には明神崎と島 $\mathrm{A}, \mathrm{B}, \mathrm{C}$ の位置を示す。島 $\mathrm{A}$ の北東側沖 約 $145 \mathrm{~m}$ に破線で示すのは長さ $210 \mathrm{~m}$, 天端幅 $25 \mathrm{~m}$ の人工 リーフである。 また明神崎と水島の開口部北側の $-2 \mathrm{~m}$ 付 近にも長さ $90 \mathrm{~m}$, 天端水深 $1 \mathrm{~m}$, 天端幅 $10 \mathrm{~m}$ の潜堤が設置 されている. 図-3より水島周辺の海底地形を調べると, 浦底湾側の-1〜 - $2 \mathrm{~m}$ には砂で覆われた平坦面が広がる が， $-5 \mathrm{~m}$ 以深は $1 / 5$ 勾配の急斜面で落ち込む. 水島の浦底 湾側には砂で覆われた平坦面があるのと対照的に，明神 崎の同じ側では平坦面が発達せずに急斜面へと続く点 は，明神崎と島 $\mathrm{A}$ 間の開口部からの侵入波浪が強い指向 性を有し，開口部から南に向かうことを示唆する。

水島を横断する5測線（T1-T5）の縦断形を図-4に示す. 測線 T2 に示すように水島の浦底湾側ではほぼ $1 / 150$ 勾配 の平坦面が続いた後- $3 \mathrm{~m}$ から急に $1 / 5$ 勾配で落ち込む。 ま た他の測線においても水島は水山のように水面上にその 質量のごく一部を有して発達していることが分かる. 2009 年 10 月と 2010 年 3 月の T2 に打ける縦断形変化を図-5 に示す。この間，浦底湾側では $Z=-0.4 \sim+1.4 \mathrm{~m}$ の範囲で

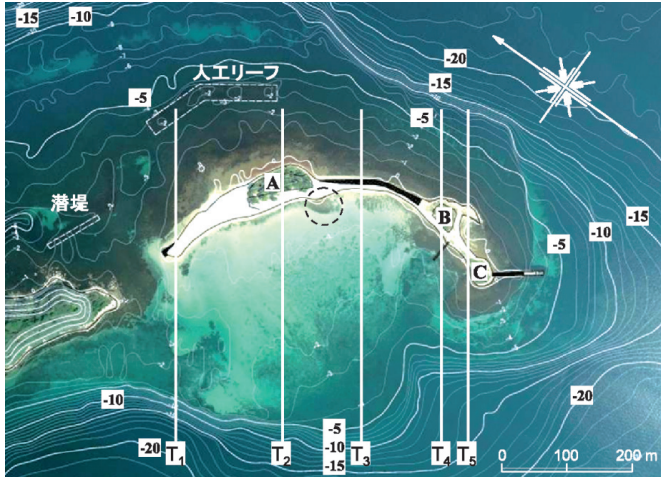

図-3 水島周辺の深浅図（2009年10月測量）

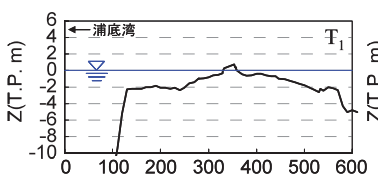

岸沖方向距離 $(\mathrm{m})$

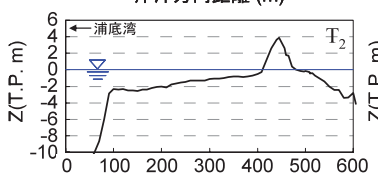

岸沖方向距離 $(\mathrm{m})$

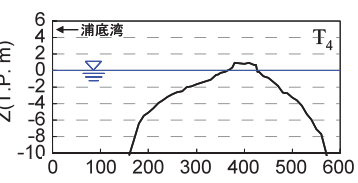

岸沖方向距離 $(\mathrm{m})$
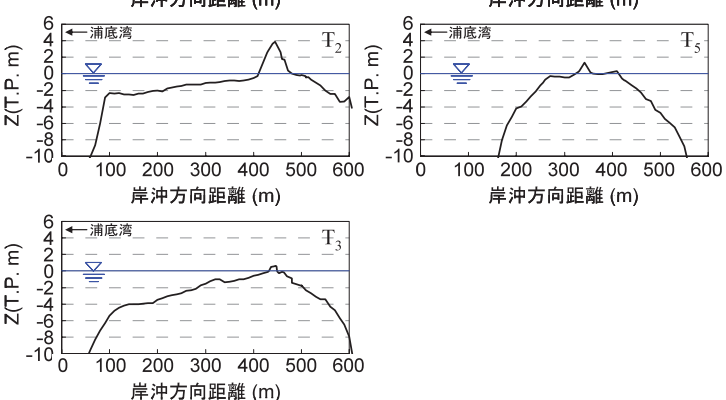

図-4 水島を横断する5測線（T1-T5）の縦断形

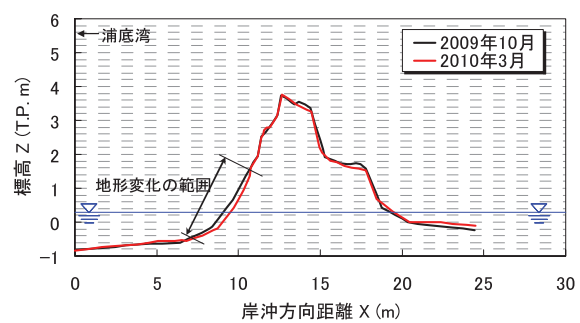

図-5 2009年10月と 2010年3月のT2における縦断形変化

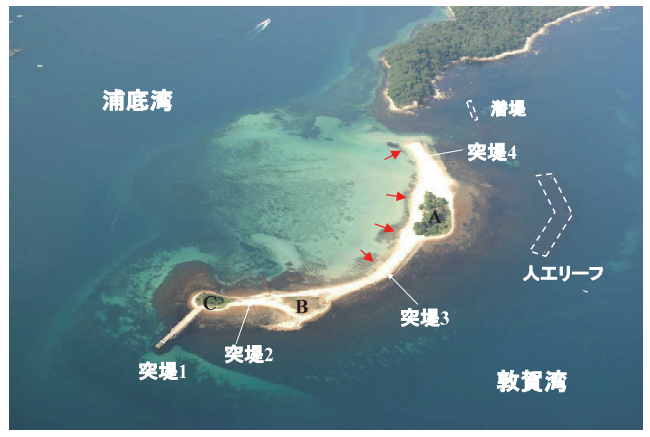

図-6 2009年3月 12 日撮影の水島の斜め空中写真 


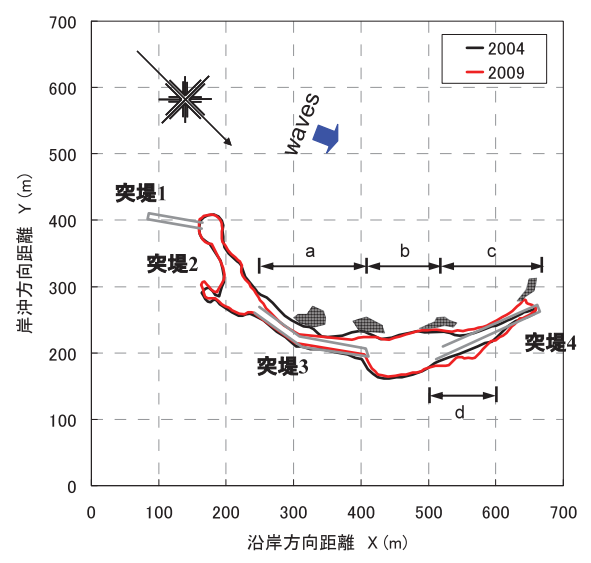

図-7 2004年と 2009年の水島の汀線形状

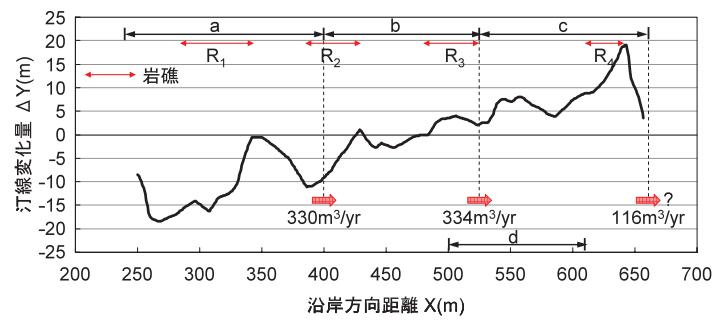

図-8 区域 $\mathrm{a} \sim \mathrm{c}$ の汀線変化

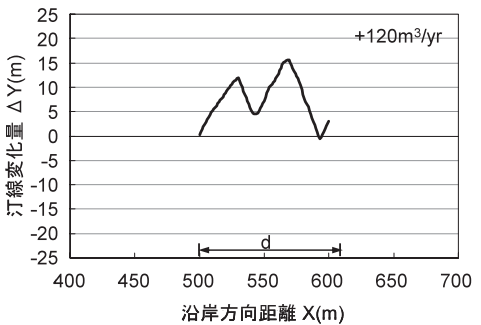

図-9 区域 $\mathrm{d}$ における汀線変化

地形変化が起きた。侵食断面積変化と汀線変化より, 漂 砂の移動高を算出すると約 $1 \mathrm{~m}$ となる.

図-6は，2009年3月 12 日撮影の水島の斜空中写真を 示す．撮影時海水透明度が高かったために浅海部の海底 地形状況が良好に判読できる．水島の敦賀湾側の海底面 は磯でありそこに海藻が密生しているため黒い。海藻に 覆われた部分は南西端に伸びた突堤 1 を超えて砂嘴のよ うに浦底湾側へと伸びている. 白い部分が砂の堆積域で, 敦賀湾側にあっては砂の堆積域は陸上に限られ，そのす ぐ沖は転石で覆われている。

図-7には2004年と 2009年の汀線形状を示す．突堤3の 南端よりも南側では汀線変化がほとんどないことから， 図中の区域 $\mathrm{a} \sim \mathrm{d}$ での汀線変化を調べた，図-8は区域 $\mathrm{a} \sim \mathrm{c}$ の汀線変化を示す。これによると区域aでは汀線が後退 する一方，区域cでは汀線が大きく前進しており，汀線

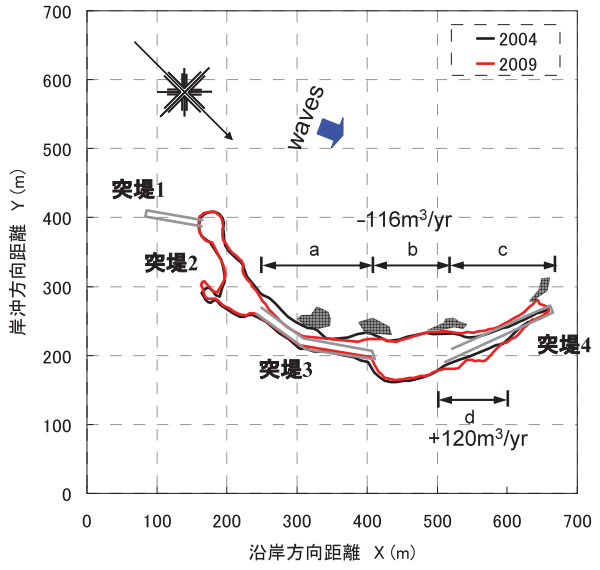

図-10 土砂バランス

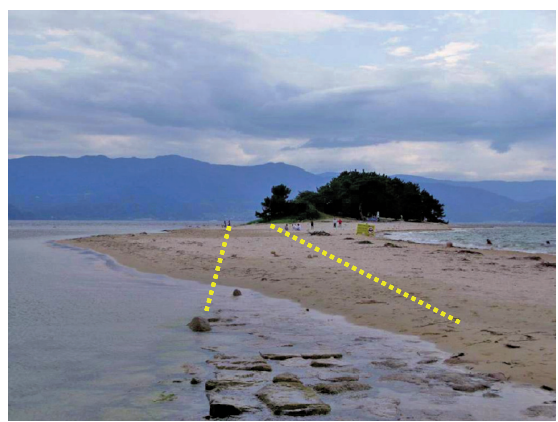

図-11 突堤 4の天端を乗り越える砂の流出状況（2009年 8 月 29 日撮影)

変化から見ると北向きの沿岸漂砂が起きたことが分かる. また $\mathrm{R}_{1} \sim \mathrm{R}_{4}$ で示す岩礁からわずかに北側にずれた場所で は舌状砂州の発達が見られる。汀線の変化面積に漂砂の 移動高（1m）を乗じ，経過時間で除して沿岸漂砂量を算 定すると，区域aの北端を通過した漂砂量は $330 \mathrm{~m}^{3} / \mathrm{yr}$ ，区 域 $\mathrm{b} て ゙ は 334 \mathrm{~m}^{3} / \mathrm{yr}$ であった．対象区域北部に位置する区域 cの北端は漂砂の自由境界であり漂砂流出の可能性があ る.一方，図-7に示すように区域 $\mathrm{c}$ と敦賀湾側の区域 $\mathrm{d}$ は 背中合わせの関係にあって，その間は天端高がT.P. $+0.5 \mathrm{~m}$ の突堤 4 で区切られているのみである. よって突堤 4 を横 切って浦底湾側から敦賀湾側へと砂が流出した可能性も ある。この段階ではいずれとも特定できないが，区域 $\mathrm{c}$ から $116 \mathrm{~m}^{3} / \mathrm{yr}$ の割合で漂砂が流出したことは間違いない。

上記漂砂の原因を特定するために，図-9には突堤 4 の

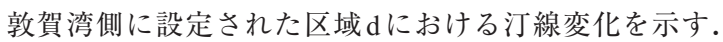
これによると区域dでは区域cでの土砂損失量とほぼバラ ンスする $120 \mathrm{~m}^{3} / \mathrm{yr}$ の割合で堆砂が起きていることが分か

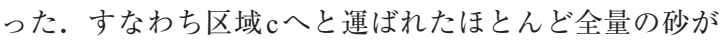
突堤 4 の天端を乗り越えて区域dへと流出したと推察で きる（図-10）。このように突堤 4 の天端を乗り越えて砂 が流出している状況は現地でも観測された（図-11）. 


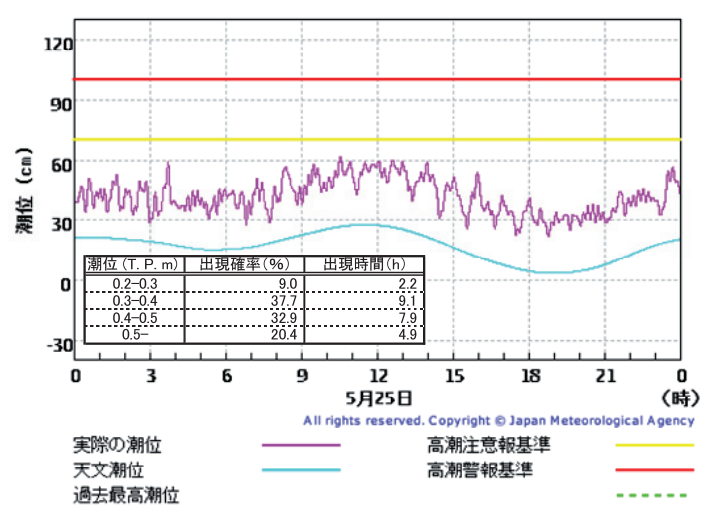

図-12 低気圧の来襲した2010年5月25日における敦賀港の潮位 変化

\section{4. 敦賀湾の湾水振動}

図-5によれば，海浜変形は標高 $+1.4 \mathrm{~m}$ までの範囲で生 じている。しかし浦底湾側に作用する平均波高は $0.2 \mathrm{~m}$,

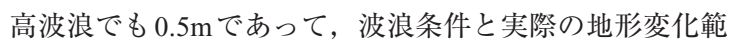
囲は対応しない. そこで低気圧来襲時の潮位について解 析した。図-12 は低気圧の来襲した 2010 年 5 月 25 日の潮 位変化を示す。これによると天文潮位から $0.3 \mathrm{~m}$ の水位上 昇が見られる。またMEMおよびFFT法によるスペクト ル解析によれば, 約 1 時間周期での副振動が起きていた. このことから, 突堤 4 の天端を乗り越える砂の流出が起 こった原因は, 低気圧の来襲による高波浪および水位上 昇によるものと推察される. すなわち浦底湾側の海浜に おいては, 通常卓越するSSE方向からの風波の作用と, 年数\%確率で来襲する低気圧による急激な水位上昇とそ れに伴う高波浪の作用により変形が起きたと考えられる.

\section{5. 急激な水位上昇を伴う場合の地形変化予測}

潮位上昇の影響を考慮するために図-13に示すように 平常時と低気圧来襲時の 2 種類の波による地形変化範囲 を設定するとともに, 水位に合わせて漂砂量の水深方向 分布関数を変えた，計算で使用する波については，磯部 （1986）の放物型モデルから得られた波向を区域 $\mathrm{a} \sim \mathrm{c}$ の それぞれの範囲において平均化するとともに, 遮蔽を考 慮するために区域 $\mathrm{a} \sim \mathrm{c}$ それそれでの平均波向を入力值と して酒井ら（2002）の方向分散法によって波高・波向を 算出し，重み付け平均を行った波を使用した（図-14）. 図-15は2004年の実測地形を示す。計算ではこれを初期 地形とした。図の破線で囲む区域の拡大図が図-16であ る.計算では現地状況に合わせるために，低気圧来襲時 に潮位が上昇した場合，波の作用期間に対応させて $116 \mathrm{~m}^{3} / \mathrm{yr}$ の割合で $\mathrm{c}$ 区間から砂を吸い达む条件を設定し た.さらに, 岩礁 $\mathrm{R}_{1} \sim \mathrm{R}_{4}$ の透過率は現況再現においても

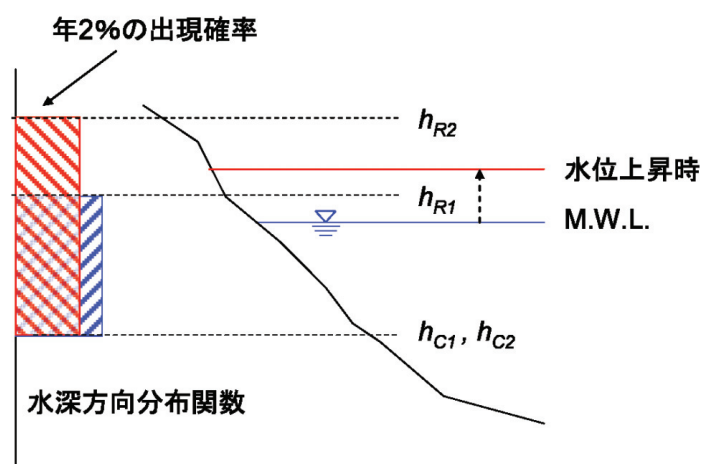

図-13 平常時と低気圧来襲時の地形変化範囲

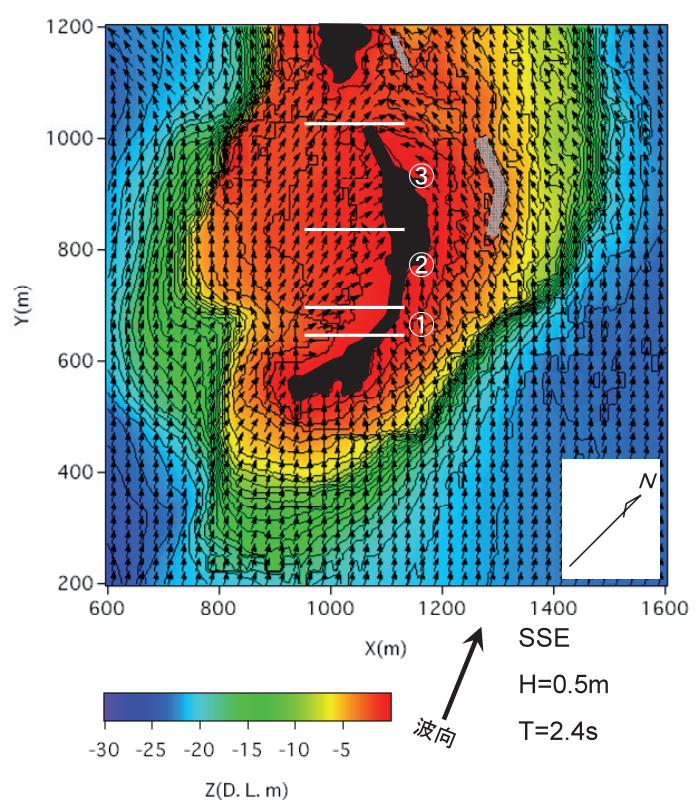

図-14 方向分散法によって求めた波浪場

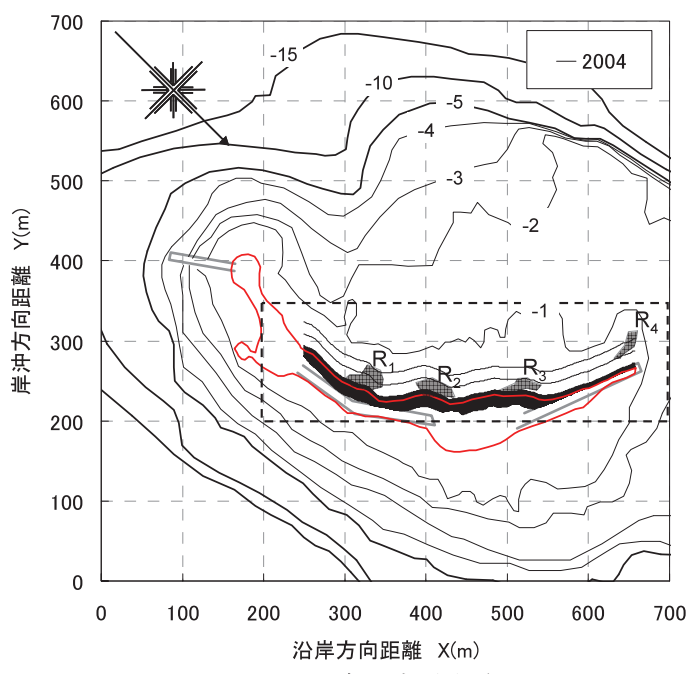

図-15 2004年の実測地形 


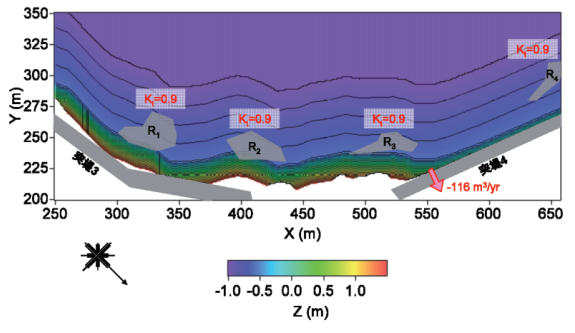

図-16 図-15の矩形域の拡大図

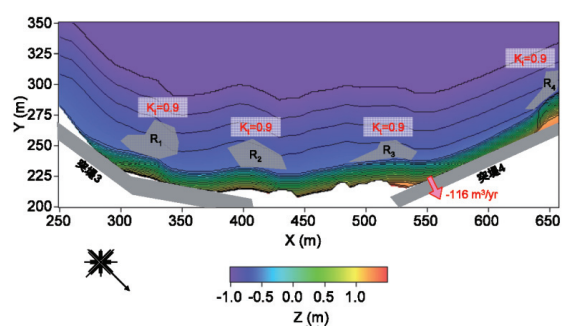

図-17２009年の再現計算結果

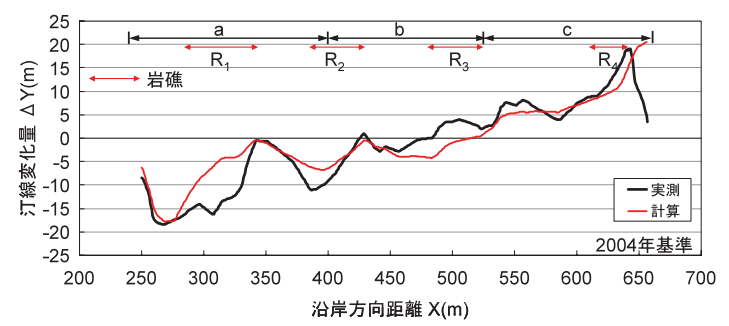

図-18 実測と計算の汀線変化

地形変化の一致度が最も高い值を使用し，透過率をそれ ぞれ 0.9 とした。底質粒径は現地砂の粒径 $0.3 \mathrm{~mm}$ を，ま た，平衡勾配については現地の前浜勾配1/10をそのまま 用いた。 その他の計算条件を表-1に示す。

図-17は2009年の地形の再現計算の結果を示す。突堤3 の前面に堆積していた砂が突堤4方向に移動するという 現象の再現ができている．図-18は実測と計算の汀線変 化を示す，岩礁による波の遮蔽効果によりトンボロ形状 が残されつつ，汀線変化が起こる現象がうまく再現でき ている．また，トンボロの形成位置および汀線変化量の オーダーも一致している。このようにして急激な水位上 昇を伴う場合の海浜変形予測が可能となった.

\section{6. まとめ}

敦賀湾北部に位置する水島では近年変形が続いてきた が，水島での海浜形状の実測デー夕や低気圧通過時の潮 位の変動を調べ，これらをもとに野志ら（2008）の等深 線変化モデルによる計算を行ったところ，実測の海浜変 形が低気圧通過時の水位上昇を伴う波浪条件に主に起因 することが明らかになった。
表-1 計算条件

\begin{tabular}{|c|c|}
\hline 数值計算法 & $\begin{array}{l}\text { 粒度組成と個々の粒径に対応した複合平衡勾配を考 } \\
\text { 虑した海浜地形·粒径変化予測モデル（野志ら,2008） } \\
\text { 放物型モデル(磯辺,1986） } \\
\text { 方向分散法(酒井ら,2003） }\end{array}$ \\
\hline 計算対象 & 突堤3南端～突堤4北端の浦底湾側 $(\mathrm{X}=250 \sim 657 \mathrm{~m})$ \\
\hline 計算ケース & 現況再現 \\
\hline 初期地形 & 2004年の実測地形 \\
\hline 底質粒径 & $0.3 \mathrm{~mm}$ \\
\hline 平衡勾配 & $1 / 10$ \\
\hline 入射波条件 & $\begin{array}{l}\text { 常時波浪 } \mathrm{H}_{1}=0.2 \mathrm{~m} \text {, 低気圧来襲時波浪 } \mathrm{H}_{2}=0.5 \mathrm{~m} \text {, 砕波角 } \alpha_{\mathrm{b}} \\
\text { 磯辺 }(1986) \text { 抢よび酒井ら }(2002) \text { の結果を用いて重 } \\
\text { み付け平均を行った波向を使用 (図-14) }\end{array}$ \\
\hline 水位条件 & $\begin{array}{l}\text { 常時波浪 T. P. }+0.2 \mathrm{~m}(\text { M. W. L. }) \\
\text { 低気圧来襲時波浪 } \quad \text { T. P. }+0.5 \mathrm{~m}\end{array}$ \\
\hline 地形変化範囲 & $\begin{array}{l}\text { 常時波浪:バーム高 } \mathrm{h}_{\mathrm{R}}=+0.4 \mathrm{~m} \text {, 波による地形変化の限界水深 } \\
\mathrm{h}_{\mathrm{C}}=-0.4 \mathrm{~m} \text {, 低気圧来襲時波浪: } \mathrm{h}_{\mathrm{R}}=+1.2 \mathrm{~m}, \mathrm{~h}_{\mathrm{C}}=-0.4 \mathrm{~m}\end{array}$ \\
\hline 境界条件 & $\begin{array}{l}\text { 左右端を固定境界, } \\
\text { 低気圧来襲時 } \\
\text { X=550 mに执いて } 116 \mathrm{~m}^{3} / \mathrm{yr} \text { の吸い込み }\end{array}$ \\
\hline 漂砂量係数 & $\begin{array}{l}\text { 漂砂量係数 } \mathrm{A}=0.03 \\
\text { 小笹·ブランプトン項の係数 } \quad \zeta=0.7 \\
\text { 岸沖漂砂量係数 } \mathrm{K}_{\mathrm{Z}} / \mathrm{K}_{\mathrm{X}}=0.1\end{array}$ \\
\hline 漂砂量の水深分布 & 一様分布 \\
\hline 土砂落ち达みの限界勾配 & 陸上::1/2,水中:1/3 \\
\hline 計算範囲 & $X=250 \sim 675 \mathrm{~m}, Z=1.5 \sim-1 \mathrm{~m}$ \\
\hline 計算メッシュ & $\Delta \mathrm{X}=1 \mathrm{~m}, \Delta \mathrm{Z}=0.1 \mathrm{~m}$ \\
\hline 計算時間間隔 $\Delta \mathrm{t}$ & $\Delta \mathrm{t}=1 \mathrm{~h}$ \\
\hline 計算ステップ数 & 1 年間: 8,760 ステップ \\
\hline 数値計算法 & 陽解法による差分法 \\
\hline
\end{tabular}

参 考 文 献

磯辺雅彦（1986）：放物型方程式を用いた不規則波の回折・屈 折・确波変形の計算法：海岸工学講演会論文集, 第33巻, pp.134-138.

宇多高明（2004）：海岸侵食の実態と解決策，山海堂，p. 304. 宇多高明 - 辻岡雄樹 - 西村隆吉 - 西岡陽一 一星上良幸 - 小澤弘 樹・野志保仁（2011）：福井県水島に打ける防波堤の建設 に伴う海浜変形，地形，第32巻，pp.29-48.

酒井和也 - 小林昭男 - 宇多高明 - 芹沢真澄 - 熊田貴之 (2003) : 波の遮蔽構造物を有する海岸における3次元静的安定海浜形 状の簡易予測モデル，海岸工学論文集，第 50巻，pp.496-500.

野志保仁・小林昭男・宇多高明（2008）：粒度組成と個々の粒 径に対応した複合平衡勾配を考慮した海浜地形・粒径変 化予測モデル，地形，第29巻，第4号，pp.399-419.

福井県地質図 2010 年度版（2010）：財団法人福井県建設技術公 社，電子版 $\mathrm{CD}$.

Uda, T. (2010): Japan's Beach Erosion - Reality and Future Measures, World Scientific, p. 418. 